\title{
Determining the musculoskeletal problems of academicians who transitioned to distance education during the COVID-19 pandemic
}

\author{
Deniz S. Yorulmaz ${ }^{\mathrm{a}, *}$, Havva Karadeniz ${ }^{\mathrm{b}}$, Seçil Duran ${ }^{\mathrm{c}}$ and İsa Çelik ${ }^{\mathrm{d}}$ \\ ${ }^{a}$ Nursing Department, Faculty of Health Sciences, Artvin Çoruh University, Artvin, Turkey \\ ${ }^{\mathrm{b}}$ Public Health Nursing, Faculty of Health Sciences, Karadeniz Technical University, Trabzon, Turkey \\ ${ }^{\mathrm{c} S}$ Siran Vocational School of Health Services, Gümüsshane University, Gümüşane, Turkey \\ ${ }^{\mathrm{d}}$ Faculty of Nursing, Dokuz Eylül University, Izmir, Turkey
}

Received 8 June 2021

Accepted 5 October 2021

\begin{abstract}
.
BACKGROUND: Musculoskeletal disorders are a significant public health issue that negatively affects individuals and society both socially and economically, and increases the cost of care and cure.

OBJECTIVE: This study aimed to determine the musculoskeletal problems and risk factors of academicians who transitioned to provide distance education during the COVID-19 pandemic.

METHODS: The population of this descriptive cross-sectional study included academicians who worked in two public universities in Turkey. Ethical committee approval and institutional permissions were obtained between 1 and 28 February 2021. Data were collected using a personal information form, the Work Environment Evaluation Questionnaire, and the Musculoskeletal Pain Intensity Assessment Questionnaire. The data were analyzed using the number, percentage, independent group $t$-test, ANOVA test, and linear regression analysis (forward method). The analysis was interpreted at the $95 \%$ confidence level and 0.05 error margin.

RESULTS: Of the academicians, $78 \%$ were women, $54.6 \%$ were married, $80.6 \%$ did not regularly exercise, and $73.5 \%$ had more workload during the distance education period. Academicians mostly experienced discomfort about their eyes, necks, and waists, and an increase at a significant level was detected in their musculoskeletal system problems during the distance education period. Increasing workload, duration of mobile phone use, active time, having an ergonomic chair, and gender predicted the musculoskeletal system pain intensity by $20 \%$.

CONCLUSION: Musculoskeletal system problems are a significant public health issue. Academicians should be informed and consulted for the protection of musculoskeletal system health during the distance education period.
\end{abstract}

Keywords: COVID-19, distance education, musculoskeletal system, universities

\footnotetext{
*Address for correspondence: Deniz S. Yorulmaz, Research Assistant, PhD Student, Nursing Department, Faculty of Health Sciences, Artvin Çoruh University, Artvin, Turkey. E-mail: denizyrlmz.20144@gmail.com.; ORCID: 0000-0001-7115-5673.
}

\section{Introduction}

The novel coronavirus pandemic, which starting in China in December 2019, has been accepted as a pandemic by the World Health Organization (WHO) after it being detected in more than one continent at the same time $[1,2]$. This rapid global change has 
led to radical changes in various fields and sectors from tourism to health, transportation, and production [3-5]. The education sector has experienced these changes at the most [6]. This new educational period was intended to be managed using various online platforms and interactive methods to meet the changing requirements and requests of education during the COVID-19 pandemic [6]. In Turkey, with the decree from the Council of Higher Education dated March, 2020, all universities began providing distance education and tried to ensure the continuity of education on digital media during the COVID-19 pandemic. The continuation of the distance education period was to be decided based on the progress of the pandemic. Distance education has been a significant step in terms of reducing infection and controlling the pandemic; however, it has also brought some negativities regarding academicians' health with it [7]. These negativities may include the increasing duration of screen time, preparing and presenting online courses, using mouse, immobility, increasing time spent on online platforms, and musculoskeletal system-related disorders $[6,7]$.

Musculoskeletal system disorders (MSDs) include pain, movement restriction, and reduced functional ability in bones, muscles, tendons, cartilage, and connective tissues [8]. Risk factors for MSDs include lack of knowledge regarding ergonomics, longer working duration, ergonomically inadequate working environment, wrong posture/position, lack of physical activity, sedentary life, and perceived stress [9, 10]. Using a computer for two and more hours a day poses a risk for MSDs regarding neck, shoulder, hand, wrist, back, waist while using a mouse for five and more hours increases the rate of elbow pain by $25 \%$ $[11,12]$. Each one-hour increase in the use of the keyboard increases the rate of hand, arm, and elbow disorders by $4 \%$ while using a mouse for four and more hours a day poses the risk for carpal tunnel syndrome $[11,12]$. Furthermore, MSDs psychosocially and negatively affect individuals and decrease the quality of life $[11,12]$. MSDs are the fundamental reason for disability and have various negative effects and financial losses for the individual, family, industry, employer, health system, and country [10]. Sagat et al. stated that annual costs of waist pains in the USA exceeded 100 billion dollars [13]. MSDs are a health problem that can be seen in every age group and every type of employee. Durmaz et al. stated that the rate of MSDs among those working with a computer ranged from $10 \%$ to $86 \%$ [14]. Grant et al. stated that $42 \%$ of the Australian surgeons experienced MSDs during the last year [15]. Kibret et al. stated that the prevalence of MSDs is $65.5 \%$ in bank employees while Kurnaz Ay et al. stated the prevalence of MSDs as $79 \%$ in white-collar employees $[10,16]$. Özdinç et al. reported that $63.4 \%$ of academicians in Turkey complain of neck and back pain [17]. MSDs can be significantly prevented and reduced with periodical training, short breaks during work, office exercises, regular physical activity, and correct posture while working [18].

Various countries put various practices such as 'stay at home', home-office, quarantine-lockdown, restrictions in the social life on their agendas to reduce the spread of the virus and get the pandemic under control $[8,19]$. The prevalence of MSDs has been affected by radical changes in daily life, decreasing physical activities, home offices, increasing time spent on online platforms during this pandemic [20]. Amro et al. stated that university students' usage duration of laptop/computers and mobile phones, and MSDs increased during the quarantine [8]. Şengül et al. stated that the rate of MSDs significantly increased before and after the quarantine in Turkey, and this rate increased more in those who did not do physical activities [20]. Smith et al. stated that MSDs increased by $52.1 \%$ during quarantine in the United Kingdom [21].

Academicians in Turkish universities are assigned to many personnel cadres such as professors, associate professors, assistant professors, lecturers, doctors, research assistants, and research associates. Thus, academicians can be referred to as "university teachers" [22]. All universities moved to distance education by the decree of Council of Higher Education in Turkey to maintain education and training period during the COVID-19 pandemic. Academicians simultaneously performed many processes such as online presentation preparation, uploading files to the system, online recitations, online student counseling, and online management of organizational duties and assignments. The rate of academicians' use of technological devices such as computers, tablets, and cellphones increased due to the preparation and presentation of courses, student counseling, and limitations on social life because of the COVID-19 pandemic whereas their active times and physical activities decreased [7]. Furthermore, because distance education was implemented for the first time, the lack of knowledge, and inexperience regarding the system complicated this period.

MSDs are a significant public health issue, which negatively affects individuals and society both socially and economically, and increases the cost of 
care and cure. The COVID-19 pandemic caused rapid changes in the entire world in various fields, education in particular. Therefore, this study aimed to determine the MSDs experienced by academicians during the distance education period and its risk factors and to contribute to the literature.

\section{Methods}

\subsection{Objective and type of the study}

This descriptive cross-sectional study aimed to determine MSDs experienced by academicians as they transitioned to distance education during the COVID-19 pandemic and its risk factors.

\subsection{Population and sample of the study}

The population of the study included academicians who worked at the Artvin Çoruh University and Gümüşhane University. The total number of academicians working in these universities was 1,178 , of whom 547 worked at the Artvin Çoruh University, and 631 worked at the Gümüşhane University. However, the number of actively working academicians is unknown due to reasons such as education, assignment, and parental leave. The sample size was calculated using a table suggested in the "estimation of a ratio in society to a certain extent". The table is used to calculate the necessary sample size to $95 \%$ confidently estimate $\mathrm{p}$ (expected mass ratio) within a numeric percentage point of $d$ (deviation made in the prevalence of the event) [24]. Another study on the same subject was referred to as a finding regarding MSDs in academicians [9]. The sample size was determined to be 369 by accepting the expected mass rate (p) to be 0.40 , the confidence level to be $95 \%$, and the relative risk to be $5 \%$. This study ended up examining 381 academicians. All participants were academicians.

\subsection{Inclusion and exclusion criteria of the study}

Academicians diagnosed with any MSDs were excluded from the study regardless of when they were diagnosed because their pain scores would be high. Also, academicians who did not volunteer to participate in the study were excluded. This study included academicians who worked at Artvin Çoruh University and Gümüşhane University in Turkey during the 2020-2021 academic year, volunteered to participate in the study, and were not diagnosed with any MSDs.
All stages of the study were carried out in accordance with ethical principles and data were collected on a voluntary basis.

\subsection{Data collection tools}

Data were collected using a Personal Information Form, the Work Environment Assessment Questionnaire, and the Musculoskeletal Pain Intensity Assessment Questionnaire developed by researchers after reviewing the relevant literature.

\subsubsection{Personal information form}

This form includes 20 questions about age, gender, marital status, regular exercises, etc.

According to the WHO, BMI is calculated as $\mathrm{kg} / \mathrm{cm}^{2}$ and classified as $<18.4 \mathrm{~kg} / \mathrm{m}^{2}$ is underweight, $18.5-24.9 \mathrm{~kg} / \mathrm{m}^{2}$ is normal weight, $25.0-29.9 \mathrm{~kg} / \mathrm{m} 2$ is overweight, and $<30.0 \mathrm{~kg} / \mathrm{m}^{2}$ is obese [23]. The BMIs of academicians were calculated with the height and weight data provided on the personal information form and they were grouped in line with the WHO's abovementioned classification.

The WHO advises adults to exercise at least 30 minutes a day to increase their quality of life and preserve physical and mental health [23]. The WHO's recommendation for adults to perform physical activity was explained to academicians on the personal information form, and the academicians were grouped as "performing physical activities" and "not performing physical activities" based on their answers.

Chronic diseases are defined as diseases that have no definitive treatment or require long-term treatment and care, medication, nursing care, a modified diet, or other methods and include high blood pressure, diabetes mellitus, asthma, cardiovascular diseases, and MSDs [8]. The definition of chronic disease was explained to academicians on the personal information form, and the academicians were grouped as "has a chronic disease" and "does not have a chronic disease" based on their answers.

The passive time stated in the Personal Information Form referred to the time spent watching television, sitting down, lying down, sitting at the table, etc., and the answers were evaluated as "increased", "remained the same", and "decreased".

\subsubsection{The work environment assessment questionnaire}

This form includes six questions evaluating the work environment at a school/faculty and home. 


\subsubsection{The MSS pain intensity assessment questionnaire}

This form was developed by researchers after reviewing the literature to assess the musculoskeletal system (MSS) pain intensity experienced by the participants. This five-point Likert-type [1(Mild) $-2-3-$ 4-5 (Very Severe)] questionnaire includes nine statements such as "Please mark the intensity if you have experienced neck pain during distance education", "Please mark the intensity if you have experienced shoulder pain during distance education", "Please mark the intensity if you have experienced waist pain during distance education". Each answer of "Mild" is one point, whereas each answer of "Very Severe" is five points. If the person has not experienced any pain regarding the stated MSDs, the score is 0 . If all questions are answered as "Very Severe", the obtained score is 45 ( 9 answers of "Always experienced" $\times 5$ points $=45$ Points). The MSS pain intensity experienced by the person increases in line with the score obtained from the questionnaire. Opinions of five experts working as faculty members in the Public Health Nursing Department were received for the questionnaire. The experts scored each question between 1 and 4 (1= Item is not appropriate, $2=$ Item should be reviewed, $3=$ It is appropriate and should slightly be reviewed, and $4=$ Item is appropriate). The scope validity index was used to evaluate the experts' opinions. Items with a scope validity index of 0.80 and more remained in the questionnaire whereas items with an index below 0.80 were excluded from the questionnaire. The scope validity index of the items included in the questionnaire ranged from 0.89 to 1.00 . The item-based scope validity index is required to be more than 0.80 in the literature [25]. The questionnaire, about which experts agreed, was administered to a group of 30 individuals with the same characteristics as the sample group chosen for the pilot practice. No negative feedback was given regarding the clarity of the scale after the pilot testing. The Cronbach's alpha value was found as 0.85 after the pilot study to determine the reliability of the questionnaire. The Cronbach's alpha value of a measurement tool is expected to be 0.80 and more in the literature [26]. Table 1 presents the content of the questionnaire finalized after the experts' opinions and the pilot study. This study calculated the Cronbach's alpha value of the MSS Pain Intensity Assessment Questionnaire to be 0.87 .

\subsection{Data collection}

The data were collected online between 1 and 28 February 2021 on a voluntary basis using institutional email addresses (i.e. ...edu.tr). It took approximately 5 to 10 minutes to complete the questionnaire. The data were collected after the permissions of the Ministry of Health, the ethical committee (Number: E-18457941-050.01.04-14075, Date: 12.31.2020), and the institutions were obtained. There were no missing answers or data because the data were collected using the online data collection method. No missing data completion method was used in the data analysis.

\subsection{Dependent, independent variables of the study and study questions}

Independent variables of the study were the sociodemographic characteristics of the academicians. The dependent variable of the study was the MSS Pain Intensity Assessment Questionnaire score of the academicians during the distance education period.

\subsection{Data analysis}

The data were analyzed using the Statistical Package for Social Sciences (SPSS) 24.0 software. Number, percentage, and mean were used in descriptive statistics. The normality distribution of the total score on the MSS Pain Intensity Assessment Questionnaire was tested using parametric tests. This study used the $t$-test for independent groups in the analysis

Table 1

MSS pain intensity assessment questionnaire

\footnotetext{
Please mark the intensity if you have experienced eye pain during distance education.

Please mark the intensity if you have experienced neck pain during distance education.

Please mark the intensity if you have experienced shoulder pain during distance education.

Please mark the intensity if you have experienced waist pain during distance education.

Please mark the intensity if you have experienced elbow pain during distance education.

Please mark the intensity if you have experienced hand-wrist pain during distance education.

Please mark the intensity if you have experienced thigh pain during distance education.

Please mark the intensity if you have experienced knee pain during distance education.

Please mark the intensity if you have experienced foot-ankle pain during distance education.
} 
of variables in two groups (gender, marital status, etc.) and used the ANOVA test for the analysis of variables in three and more groups (duration of computer use, duration of mobile phone use, etc.). Furthermore, the significance between the variables in three and more groups was examined using Tukey's test. The prediction levels of participants' sociodemographic characteristics of MSS pain intensity scores were examined using the linear regression analysis (forward method). Academicians in Turkish universities work within the scope of many personnel cadres such as professors, associate professors, assistant professors, lecturers, doctors, research assistants, and research associates [22]. Academicians were grouped and evaluated in two groups as having completed or not completing/continuing a doctorate program (Ph.D. + and Ph.D. -) based on their educational level to organize the data and facilitate international comprehensibility. The level of significance was set at $p<0.05$, and the confidence level was set at $95 \%$ in the prediction of all analysis results.

\section{Results}

The participants' sociodemographic characteristics and descriptive information are presented in Table 2. Of the academicians, $78 \%$ were female, $54.6 \%$ were married, and $50.3 \%$ had one child. Of them, $19.4 \%$ exercised regularly and $12.3 \%$ exercised in the office during the day (Table 2).

Figure 1 presents the changes experienced by academicians. During distance education, the duration in which $64 \%, 93.4 \%$, and $93.4 \%$ of the academicians were passive, used a computer, and used a mobile phone, respectively, increased whereas the duration in which $78.2 \%$ of them were active decreased (Fig. 1).

The comparison of MSDs experienced by academicians before and during the distance education period is given in Figure 2. Before the distance education period, $64 \%$ of the academicians had an MSDs whereas the rate of academicians with MSDs increased to $70.6 \%$ during the distance education period. Disorders related to the eye, neck, back, elbow, hand-wrist, thigh, knee, and foot-ankle increased during the distance education period.

Pain intensity levels based on the changes experienced by the academicians during distance education are listed in Table 4 . The pain scores of the participants whose passive time increased were significantly higher than that of the participants whose passive time remained the same $(p<0.05)$ (Table 3$)$. Similarly, the
Table 2

Academicians' sociodemographic characteristics and descriptive information

\begin{tabular}{|c|c|c|}
\hline Characteristics & $n$ & $\%$ \\
\hline \multicolumn{3}{|l|}{$\overline{\text { Gender }}$} \\
\hline Female & 297 & 78.0 \\
\hline Male & 84 & 22.0 \\
\hline \multicolumn{3}{|l|}{ Education status } \\
\hline Ph.D.+ & 115 & 30.2 \\
\hline Ph.D. - & 266 & 69.8 \\
\hline \multicolumn{3}{|l|}{ Marital status } \\
\hline Married & 208 & 54.6 \\
\hline Single & 173 & 45.4 \\
\hline \multicolumn{3}{|l|}{ Number of children } \\
\hline 1 & 80 & 50.3 \\
\hline 2 & 67 & 42.1 \\
\hline 3 and more & 12 & 7.5 \\
\hline \multicolumn{3}{|l|}{ Body mass index } \\
\hline Underweight $\left(\mathrm{BMI}<18.4 \mathrm{~kg} / \mathrm{m}^{2}\right)$ & 30 & 7.9 \\
\hline Normal $(18.5 \leq \mathrm{BMI} \leq 24.9)$ & 202 & 53.0 \\
\hline Overweight $\left(\mathrm{BMI}=25.0-29.9 \mathrm{~kg} / \mathrm{m}^{2}\right)$ & 116 & 30.4 \\
\hline Obese $(30.0 \leq \mathrm{BMI} \leq 34.9)$ & 33 & 8.7 \\
\hline \multicolumn{3}{|l|}{ Chronic disease } \\
\hline Yes & 64 & 16.8 \\
\hline No & 317 & 83.2 \\
\hline \multicolumn{3}{|l|}{ Regular exercise } \\
\hline Yes & 74 & 19.4 \\
\hline No & 307 & 80.6 \\
\hline \multicolumn{3}{|l|}{ Owning ergonomic working chair } \\
\hline Yes & 133 & 34.9 \\
\hline No & 248 & 65.1 \\
\hline \multicolumn{3}{|l|}{ Exercising in the office during the day } \\
\hline Yes & 47 & 12.3 \\
\hline No & 334 & 88.7 \\
\hline \multicolumn{3}{|l|}{$\begin{array}{l}\text { Increasing workload during the } \\
\text { distance education period }\end{array}$} \\
\hline Yes & 280 & 73.5 \\
\hline No & 101 & 26.5 \\
\hline \multicolumn{3}{|l|}{ Working place during distance education } \\
\hline Usually house & 169 & 44.4 \\
\hline Usually school & 38 & 10.0 \\
\hline Both house and school & 174 & 45.7 \\
\hline
\end{tabular}

pain scores of the participants whose passive time decreased were significantly higher than that of the participants whose passive time remained the same $(p<0.05)$ (Table 3).

The pain scores of participants whose active time decreased were significantly higher than those of patients whose active time remained the same $(p<$ 0.05 ) (Table 3). Additionally, the pain scores of participants whose duration of computer use increased were significantly higher than those of patients whose duration of computer use remained the same $(p<0.05)$ (Table 3).

The pain scores of participants whose duration of mobile phone use increased were significantly higher than those of participants whose duration of mobile phone use remained the same while the pain 


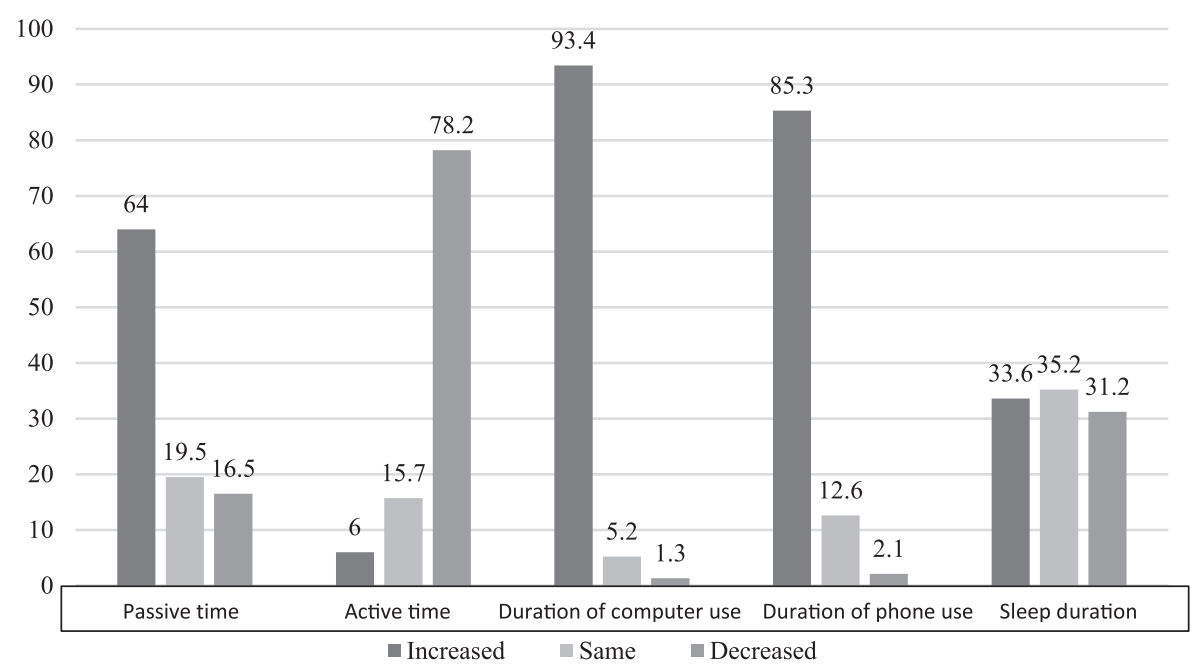

Fig. 1. Changes experienced by academicians during distance education period.

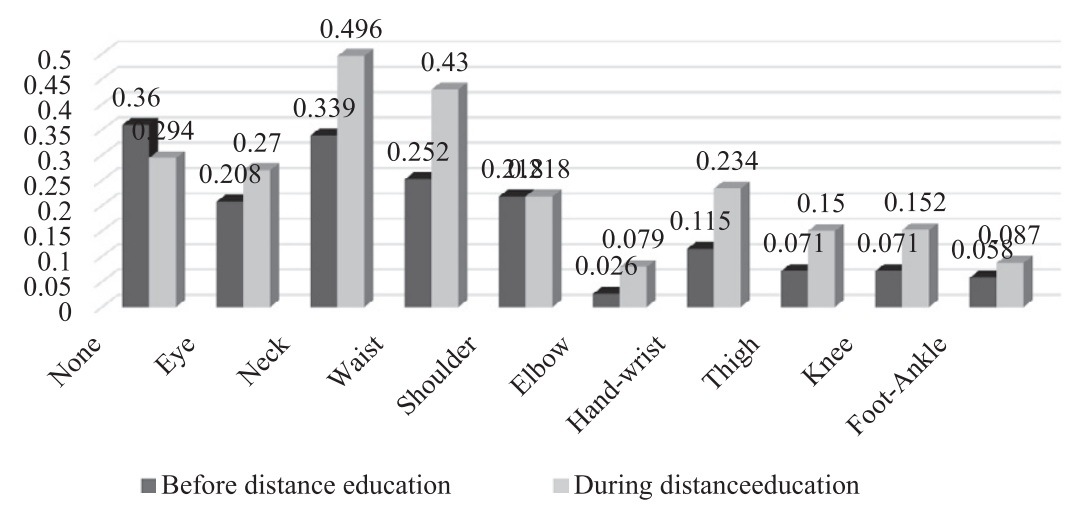

Fig. 2. Comparison of MSDs experienced by academicians before and during the distance education period.

scores of the participants whose duration of mobile phone use decreased were significantly higher than those of patients whose duration of mobile phone use remained the same $(p<0.05)$ (Table 3$)$.

The pain scores of participants whose duration of sleep increased were significantly higher than those of patients whose duration of sleep remained the same $(p<0.05)$ (Table 3). Moreover, the pain scores of participants whose duration of sleep decreased were significantly higher than those of patients whose duration of sleep remained the same $(p<0.05)$ (Table 3).

The MSS pain intensity determinants of the academicians during the distance education period were evaluated using the multiple regression analysis (Table 4). Model 1 examining the MSS pain intensity level determinants found that the increasing workload $(\beta=0.283)$, the increases in the duration of mobile phone use $(\beta=-0.147)$, and the female gender $(\beta=-0.133)$, having an ergonomic study chair $(\beta=0.105)$, and an increase in active time $(\beta=-0.103)$ affected the MSS pain intensity. These variables accounted for $20 \%$ of the MSS pain intensity level.

\section{Discussion}

The COVID-19 pandemic affected each age group and profession in the world differently. Formal education was paused in universities after the first case of COVID-19 was detected in Turkey, and the distance education period started to control the spread of the pandemic and preserve public health. Transition to distance education had been unexpected and quick for academicians [20]. Therefore, this study was conducted to determine the MSDs experienced by the academicians due to distance education during the COVID-19 pandemic and their risk factors. 
Table 3

Total MSS pain intensity assessment questionnaire score distribution of academicians $(n=381)$

\begin{tabular}{lcc}
\hline Characteristics & Mean & $p$ \\
\hline Passive time & & $p: 0.001$ \\
$\quad$ Increased (1) & $20.0 \pm 9.5$ & F: 7.037 \\
Same (2) & $13.5 \pm 11.8$ & $(1)>(2), p: 0.047$ \\
Reduced (3) & $23.0 \pm 10.7$ & $(3)>(2), p: 0.001$ \\
Active time & & $p<0.001$ \\
$\quad$ Increased (1) & $14.0 \pm 8.8$ & $\mathrm{~kW}: 14.079$ \\
Same (2) & $15.0 \pm 10.7$ & $(3)>(2), p: 0.001$ \\
$\quad$ Reduced (3) & $21.0 \pm 10.1$ & \\
Duration of using a computer & & $(1)>(2), p: 0.001$ \\
Increased (1) & $20.0 \pm 10.1$ & \\
Same (2) & $8.5 \pm 10.4$ & $p<0.001$ \\
Reduced (3) & $12.0 \pm 11.9$ & $(1)>(2), p: 0.001$ \\
Duration of using a mobile phone & & $(3)>(2), p: 0.049$ \\
Increased (1) & $21.0 \pm 10.0$ & $p<0.001$ \\
Same (2) & $12.5 \pm 11.3$ & $\mathrm{~F}: 7.855$ \\
Reduced (3) & $24.5 \pm 8.4$ & $(1)>(2), p: 0.012$ \\
Sleep duration & & $(3)>(2), p: 0.001$ \\
Increased (1) & $21.0 \pm 10.1$ & \\
Same (2) & $16.5 \pm 10.4$ & 0.020 \\
Reduced (3) & $22.0 \pm 10.0$ & $\mathrm{~F}: 3.976$ \\
Working place during distance education & & $(3)>(1), p: 0.048$ \\
$\quad$ Usually from home (1) & $18.0 \pm 9.4$ & \\
Usually from school (2) & $17.5 \pm 12.1$ & $21.0 \pm 10.7$ \\
From both home and school (3) & &
\end{tabular}

Table 4

MSS pain intensity assessment determinants (multiple regression analyses_-forward model)

\begin{tabular}{|c|c|c|c|c|c|c|}
\hline \multirow[t]{2}{*}{ Independent variables } & \multicolumn{2}{|c|}{$\begin{array}{l}\text { Unstandardized } \\
\text { coefficients }\end{array}$} & \multirow{2}{*}{$\begin{array}{l}\begin{array}{l}\text { Standardized } \\
\text { coefficients }\end{array} \\
\beta\end{array}$} & \multirow[t]{2}{*}{$\mathrm{t}$} & \multirow[t]{2}{*}{$p$} & \multirow[t]{2}{*}{$95.0 \% \mathrm{CI}$} \\
\hline & B & SE & & & & \\
\hline (Constant) & 14.528 & 1.725 & & 8.422 & 0.000 & 11,136 to 17.920 \\
\hline \multicolumn{7}{|l|}{ Passive time (R: Same) } \\
\hline Increased & -0.082 & 1.347 & -0.004 & -0.061 & 0.951 & -2.730 to 2.566 \\
\hline Reduced & 3.197 & 1.701 & 0.115 & 1.880 & 0.061 & -0.147 to 6.541 \\
\hline \multicolumn{7}{|c|}{ Active time (R: Reduced) } \\
\hline Increased & -4.479 & 2.032 & -0.103 & -2.204 & 0.028 & -8.474 to -0.483 \\
\hline Same & -2.638 & 1.416 & -0.093 & -1.863 & 0.063 & -5.421 to 0.146 \\
\hline \multicolumn{7}{|c|}{$\begin{array}{l}\text { Duration of using the mobile } \\
\text { phone (R: Increased) }\end{array}$} \\
\hline Same & -4.566 & 1.523 & -0.147 & -2.998 & 0.003 & -7.561 to -1.571 \\
\hline Reduced & 3.533 & 3.373 & 0.049 & 1.047 & 0.296 & -3.100 to 10.166 \\
\hline \multicolumn{7}{|c|}{ Owning an ergonomic chair (R: Yes) } \\
\hline No & 2.277 & 1.016 & 0.105 & 2.240 & 0.026 & 0.279 to 4.276 \\
\hline \multicolumn{7}{|l|}{ Gender (R: Female) } \\
\hline Male & -3.329 & 1.191 & -0.133 & -2.796 & 0.005 & -5.671 to -0.987 \\
\hline \multicolumn{7}{|c|}{ Increase in workload (R: No) } \\
\hline Yes & 6.627 & 1.154 & 0.283 & 5.740 & 0.000 & 4.357 to 8.897 \\
\hline
\end{tabular}

Abbreviations: CI, confidence interval; SE, standard error; $\beta$, standardized regression coefficient. Durbin-Watson $=1.772 . \mathrm{F}=10.878$, $p<0.001 . R=0.457 \mathrm{R}^{2}=0.209$, Adjusted $\mathrm{R}^{2}=19.0 \%$. ${ }^{*}$ The significance level was accepted as $p<0.05$.

This study found that gender affected the MSS pain intensity and female academicians suffered from more pain compared to male academicians. Şengül et al. found that more females suffer from MSDs during the COVID-19 pandemic than males and that their pain intensity levels are higher than those of males. Akınci et al. found that females suffer from neck, shoulder, and back pains more than males, and absence due to MSDs is more common in females than males. Kurnaz Ay et al. stated that females suffer from MSDs more than males and that loss of productivity due to MSDs is higher among females than males $[16,20,27]$. The relevant literature reports that females have less muscle tissue and more adipose tissue compared to males, they have different physiology, conducive to pregnancy and labor, from 
that of males and they suffer from MSDs more than males do $[13,16]$. Additionally, women's domestic works such as cleaning, tidying up, cooking, and motherhood roles are considered to affect MSDs [30]. Academicians should be informed about preserving the MSS health, ergonomically correct working position, correct body posture, and techniques for carrying furniture. MSDs will decrease, and productivity and quality of life will increase by preserving the MSS health and controlling the risk factors [28].

This study found no significant differences between educational status, marital status, number of children, BMI, presence of chronic diseases, and exercising in the office during the day with MSS pain intensity, and these factors were not significant determinants for MSS pain intensity. Considering the relevant literature, Algarni et al. reported that there was no significant difference between educational status and MSDs in academicians [9]. Similarly, Grant et al. found no significant difference between BMI and MSDs in Australian surgeons [15]. Kibret et al. found that marital status did not affect MSDs [10] while Kurnaz Ay reported that there was no significant difference between the presence of chronic diseases and MSDs [16]. It is considered that differences caused by the determinants of educational status, marital status, number of children, BMI, the presence of chronic diseases, or exercising in the office during the day were eliminated because all academicians were similarly affected by the changes in the education-training period and limitations to their social and daily life due to the COVID-19 pandemic.

This study found that passive and active time affected the MSS pain scores of the academicians and longer passive time indicated more intense MSS pains in academicians. Şengül et al. stated that the prevalence of MSDs and pain intensity increased, increasing passive time affected MSDs, and individuals were more inactive and exercised less during the COVID-19 pandemic compared to the pre-pandemic period. Amro et al. found that students' use of electronic devices and inactive time increased due to distance education, and the intensity of MSDs increased during the pandemic. Aytar et al. stated that students' inactive time on-screen increased, and deteriorated MSDs. Algarni et al. found that inadequate physical activity and monotonous living are related to MSDs among academicians in Saudi Arabia. Kibret et al. found that inadequate physical activity and nonstop long-term working increased MSDs in Ethiopia [7-10]. Various pandemic measurements such as the closing of gyms, weekend lockdowns, distance education during the COVID-19 pandemic increased the duration of academicians' passive time as expected. Sedentary life habits and inadequate physical activity are significant risk factors for MSDs, significantly affect the prevalence and intensity of MSDs, and are the fourth leading risk factors for global deaths [29]. Various practices such as joining online exercise programs, online professional sports support, and indoor physical activities are thought to be beneficial to minimize the negative effects of the changing life dynamics on MSS health and preserve the MSS health during the COVID-19 pandemic. Online and indoor physical activities will allow taking the inadequate physical activity, a risk factor for MSDs, under control, preserving academicians' MSS health, increasing the quality of life, and preventing MSDs' negative outcomes for individuals and society [30].

This study found that the duration of mobile phone and computer use affected MSS pain intensities of academicians. Academicians with higher duration of mobile phone and computer use had higher MSD pain scores. Amro et al. found that students used electronic devices (phone, tablet, or computer) more during the COVID-19 pandemic compared to the pre-pandemic period and that the incidence of MSDs increased in line with the higher duration of electronic device use. Çalık et al. found that government agency employees who use a computer for four or more hours a day suffer from neck pains concerning their use of computers. Sagat et al. found that individuals who work sitting down for long durations, online, or individuals who receive distance education suffer from backache more than others, and their pain intensity levels are higher. Durmaz et al. stated that secretaries using computers for four or more hours a day suffer from MSDs [8, 13, 14, 31]. Distance education, preparing for online lessons, online course presentations, system problems, and limited communication with students and other academicians during the COVID19 pandemic increased the duration of academicians' use of mobile phones and computers, which is considered mandatory and predictable. Academicians should be informed and consulted about the topics such as the use of headphones during mobile phone calls, correct mouse usage while using a computer, correct body position, office exercises in the breaks, correct lighting of the study environment, and office ergonomics to minimize the negative effects of this situation on MSDs and the quality of life. Office ergonomics training will maintain the MSS health of the academicians in the short and long term and 
prevent disorders related to MSS, increased workload, and loss of money [32].

This study indicated that $65.1 \%$ of the academicians did not have an ergonomic chair and that ergonomically proper chairs affected the MSS pain intensity level. Durmaz et al. found that a chair without ergonomically suitable height affects the shoulder pain of secretaries. Kibret et al. found that ergonomically inappropriate chairs significantly increased work-related MSDs of bank employees [10, 14]. Previous studies indicate that ergonomically inappropriate chairs and desks are related to MSDs and pain intensities, and ergonomically inappropriate working environments increase MSDs and workload and cause a loss in productivity $[6,11]$. Academicians were mostly working in their offices before distance education, and they did not have any ergonomically proper chairs in their homes due to the rapid transition to distance education. Academicians should be informed about the effects and significance of an ergonomic chair on MSDs, the place where they could buy these chairs, things they should be careful about while using such chairs. The information on this subject will be significant in terms of maintaining MSS health, preventing MSDs, preserving and increasing the quality of life [33]. Additionally, it would be beneficial for institutions to obtain information about academicians' working environments at home and take steps to improve their working environments so as to maintain their quality of life and support their productivity.

This study found that $73.5 \%$ of the academicians had more workload during the distance education period, and the increasing workload affected their MSS pain intensity. Grant et al. found that increased weekly working duration increased the MSDs among surgeons in Australia. Kibret et al. stated that the prevalence of MSDs was higher in bank employees working five and more hours a day. Gülşen stated that increased weekly working hours negatively affected hand-wrist pains [10, 15, 34]. Previous studies indicate that increased daily and weekly working durations affect MSDs and increase the prevalence and intensity of pain $[10,15]$. Academicians had more workload due to rapid migration to distance education, lack of experience regarding distance education systems, changes in term exams, and video shoots for applied courses. Academicians should be informed about making plans regarding increased workload management in the distance education period, the formation of a physical activity plan regarding the maintenance of MSS health, and stress management to maintain psychosocial wellbeing. This information made to the academicians will preserve bio-psycho-social health and decrease the negative effects induced by MSDs and the pandemic [35].

\subsection{Limitations of the study}

The results of this study support and provide new information to the current literature; however, the study has some limitations. First, this study was conducted only in two state universities in Turkey. Second, it was conducted online. Lastly, most research cited in this article were conducted before the COVID-19 pandemic using different working groups than academicians. Because the COVID-19 pandemic is a global issue affecting every age group and MSDs can be seen in any occupational group at different ages, the articles used in this study were deemed appropriate. Furthermore, cognitive and psychological causes experienced by academicians such as uncertainty, fear of the unknown, and fear of death might affect academicians' problems regarding MSDs. The results of the study can only be generalized to academicians included in the population of the study.

\section{Conclusion}

This study was conducted to determine the musculoskeletal problems of academicians who transitioned to distance education during the COVID-19 pandemic and risk factors. Accordingly, this study found that $70.6 \%$ of the academicians suffered from an MSD, the incidence of MSDs after the transition to distance education increased, and the academicians mostly suffered from MSDs related to the eye, neck, and waist. Academicians' duration of computer and mobile phone use, passive time, and workloads increased during the distance education period. Increasing workload, duration of mobile phone use, active time and ergonomic chair, and gender affected the MSS pain intensity of the academicians.

Study results support and contribute to the current literature. Information and consultancy for academicians to preserve their MSS health and prevent disorders, training sessions, and seminars regarding ergonomic working conditions, institutions' collection of information about academicians' working conditions at home, improving the working conditions at home, providing ergonomic chairs and desks, 
and publication of short videos about the subject prepared by Turkey Ministry of Health and/or Council of Higher Education are recommended. Future studies should be conducted to examine the effects of training regarding the provision of MSS health on the level of knowledge and pain intensity. Results of such studies may be guiding for the planning regarding the changes in MSDs and physical activities of individuals in the current distance education period or another pandemic period.

\section{Conflict of interest}

None declared.

\section{References}

[1] Danesh MK, Garosi E, \& Golmohamadpour H. (2021). The COVID-19 Pandemic and nursing challenges: A review of the early literature. Work. (Preprint), 2021; 1-14.

[2] Ahmed S, Zimba O, Gasparyan AY. Moving towards online rheumatology education in the era of COVID-19. Clinical Rheumatology. 2020;1-8.

[3] Falvey JR, Krafft C, Kornetti D. The essential role of home-and community-based physical therapists during the COVID-19 pandemic. Physical Therapy. 2020; 100(7):1058-61.

[4] Pugliese M, Wolff A. The Value of Communication, Education, and Self-Management in Providing Guideline-Based Care: Lessons Learned from Musculoskeletal Telerehabilitation During the COVID-19 Crisis. HSS Journal. 2020;1-4.

[5] Schwartz AM, Wilson JM, Boden SD, Moore Jr TJ, Bradbury Jr TL, Fletcher ND. Managing resident workforce and education during the COVID-19 pandemic: evolving strategies and lessons learned. JBJS Open Access. 2020;5(2):e0045.

[6] Pather N, Blyth P, Chapman JA., Dayal MR, Flack NA, Fogg QA, et al. Forced Disruption of Anatomy Education in Australia and New Zealand: An Acute Response to the Covid-19 Pandemic. Anat Sci Educ. 2020;13(3):284-300.

[7] Aytar A, Altıntaş A, Aytar A. Effects of posture and ergonomics training for students receiving distance education during the covid-19 pandemic on musculoskeletal pain, exercise behavior decision-making balance, and physical activity level. Journal of Exercise Therapy and Rehabilitation. 2020;7(2):137-144.

[8] Amro A, Albakry S, Jaradat M, Khaleel M, Kharroubi T, Dabbas A, et al. Musculoskeletal Disorders and Association with Social Media Use Among University Students at the Quarantine Time Of COVID-19 Outbreak. Journal of Physical Medicine \& Rehabilitation Studies Introduction. 2020;1(1):1-6.

[9] Algarni FS, Kachanathu SJ, AlAbdulwahab SS. A CrossSectional Study on the Association of Patterns and Physical Risk Factors with Musculoskeletal Disorders among Academicians in Saudi Arabia. BioMed Res Int. 2020. https://doi.org/10.1155/2020/8930968
[10] Kibret AK, Fisseha Gebremeskel B, Embaye Gezae K, Solomon Tsegay G. Work-Related Musculoskeletal Disorders and Associated Factors Among Bankers in Ethiopia, 2018. Pain Res Manag. 2020. https://doi.org/10.1155/ 2020/8735169

[11] Bilgin E, Kutsal YG. Bilgisayar Kullanımı ile İlişkili Boyun ve Üst Ekstremite Rahatsılılkları. STED. 2017:26(6): 251-5.

[12] Mojadam M, Ebadi Z, Ghanbari S, Hajibabaei M. The Prevalence of Musculoskeletal Disorders and Assessment of Body Status among Employees of Shahid Chamran University of Ahwaz. Archives of Occupational Health. 2018;2(4):240-4.

[13] Šagát P, Bartík P, Prieto González P, Tohănean DI, Knjaz D. Impact of COVID-19 Quarantine on Low Back Pain Intensity, Prevalence, and Associated Risk Factors among Adult Citizens Residing in Riyadh (Saudi Arabia): A Cross-Sectional Study. Int J Environ Res Public Health. 2020:17(19):7302.

[14] Durmaz E, Nazlıcan E, Akbaba M. Bir Üniversite Hastanesinde Çalışan Sekreterlerin Kas İskelet Sistemi Yakınmalarının İncelenmesi. Sakarya Tip Dergisi. 2018: 8(2);432-41.

[15] Grant KMK, Vo T, Tiong LU. The painful truth: workrelated musculoskeletal disorders in Australian surgeons. Occupational Medicine. 2020:70(1):60-3.

[16] Kurnaz Ay M, Karakuş B, Hıdıroglu S, Karavuş M, Tola AA, Keskin N, et al. Bir büronun beyaz yakalı çalışanlarında kasiskelet sistemi yakınmaları ve ilişkili faktörler. Kocaeli Tıp Dergisi. 2020:9(1):143-51.

[17] [17]-Özdinç S, Kayabınar E, Özen T, Turan FN, Yılmaz S. Musculoskeletal problems in academicians and related factors in Turkey. Journal of Back and Musculoskeletal Rehabilitation. Work. 2019;32(6):833-9.

[18] Alavi SS, Abbasi M, Mehrdad R. Risk factors for upper extremity musculoskeletal disorders among office workers in Qom province, Iran. Iran Red Crescent Med J. 2016:18(10):1-8.

[19] Cahalane AM, Cui J, Sheridan RM, Thabet A, Sutphin PD, Palmer WE, et al. Changes in interventional radiology practice in a tertiary academic center in the United States during the Coronavirus disease 2019 (COVID-19) pandemic. J Am Coll Radiol. 2020:17(7);873-7.

[20] Şengül H, Bulut A, Adalan MA. Investigation of the change of lockdowns applied due to COVID-19 pandemic on musculoskeletal discomfort. Journal of Human Sciences. 2020;17(4):974-85.

[21] Smith TO, Durrant K, Birt L, Belderson P, Chipping J, Yates $\mathrm{M}$, et al. Accessing health services for musculoskeletal diseases during early COVID-19 lockdown: Results from a UK population survey. Rheumatol Adv Pract. 2020;4(2):1-3.

[22] Yıldız S. Türkiye'de kadın akademisyen olmak. Yükse köğretim ve Bilim Dergisi. 2018;(1):29-40.

[23] WHO https://www.who.int/news/item/27-09-2002-activeageing-moving-hearts-for-healthErişimTarihi:07.05.2021

[24] Lemeshow S, Hosmer Jr DW, Klar J, Lwanga SK, Sağlık Araştırmalarında Örneklem Büyüklüğünün Yeterliliği, S. Oğuz Kayaalp (Ed.), Sağlık Araştırmalarında Örneklem Büyüklüğünün Yeterliliği, Ankara, Hacettepe TAŞ Kitapevi, 2000,143-146.

[25] Davis LL. Instrument review: Getting the most from a panel of experts. Appl Nurs Res. 1992:5;194-7.

[26] Şencan H. Sosyal ve davranışsal ölçümlerde güvenilirlik ve geçerlilik (1. Basım) Seçkin Yayıncılık Sanayi ve Ticaret AŞ, Ankara. 2005;499-559. 
[27] Akıncı B, Zenginler Y, Kaya BK, Kurt A, Yeldan İ. Beyaz yakalı çalışanlarda işe bağlı boyun, sırt ve omuz bölgelerine ait kas iskelet sistemi rahatsızlıklarının ve işe devamsızlığa etki eden faktörlerin incelenmesi. Sakarya Tıp Dergisi. 2018;8(4):712-9.

[28] Beaudart C, Biver E, Bruyère $\mathrm{O}$, Cooper $\mathrm{C}, \mathrm{Al}$-Daghri $\mathrm{N}$, Reginster J, et al. Quality of life assessment in musculoskeletal health. Aging Clin Exp Res. 2018:30(5);413-8.

[29] Davergne T, Pallot A, Dechartres A, Fautrel B, Gossec L. Use of wearable activity trackers to improve physical activity behavior in patients with rheumatic and musculoskeletal diseases: a systematic review and meta-analysis. Arthritis Care Res. 2019:71(6);758-67.

[30] Constandt B, Thibaut E, De Bosscher V, Scheerder J, Ricour M, Willem A. Exercising in times of lockdown: an analysis of the impact of COVID-19 on levels and patterns of exercise among adults in Belgium. Int J Environ Res Public Health. 2020:17(11):4144.
[31] Çalık BB, Atalay OT, Başkan E, Gökçe B. Bilgisayar kullanan masa başı çalışanlarında kas iskelet sistemi rahatsılılıları, işin engellenmesi ve risk faktörlerinin incelenmesi. MÜSBED. 2013;3(4):208-14.

[32] James C, James D, Nie V, Schumacher T, Guest M, Tessier $\mathrm{J}$, et al. Musculoskeletal discomfort and use of computers in the university environment. Appl Ergon. 2018;69:128-35.

[33] Prall J, Ross M. The management of work-related musculoskeletal injuries in an occupational health setting: the role of the physical therapist. J Exerc Rehabil. 2019;15(2):193-9.

[34] Gülşen M. Bilgisayar kullanıcılarında çalışma postürünün el ve el bileği ağrısı üzerine etkileri. Sağlık ve Toplum. 2019;29(2):92-97.

[35] Erkin Ö, Özsoy S, Gültekin T, Erkin Ö. Determınıng the exposure level of nurse academicians to risk factors for work-related musculoskeletal disorders and their relatıonshıp with pain and fatıgue. Ponte Academic Journal. 2019;75(12/1). 